\title{
Study on effect on water activity, TBA number and protein of dried chicken meat during storage
}

\section{JAVEED AKHTAR* AND P. K. OMRE}

Department of Post Harvest Process and Food Engineering, College of Technology, G.B. Pant University of Technology, Pantnagar, U.S. NAGAR (UTTARAKHAND) INDIA

Email : er.jakhtar@gmail.com

*Author for Correspondence

Research chronicle : Received : 27.09.2016; Revised : 28.10.2016; Accepted : 30.11.2016

SUMMARY :

The present experiment was envisaged to evaluate the effect of packaging methods and treatments and storage time on protein content, TBA number and water activity of dried chicken meat throughout storage period. Dehydrated chicken meat with sodium nitrite treatment was prepared by high velocity hot air drying at temperature of $55^{\circ} \mathrm{C}$ and air velocity of $5.5 \mathrm{~m} / \mathrm{s}$. Protein content, TBA number and water activity were determined after 15 days interval during storage of 150 days. Effect of packaging methods and treatments and storage time of dried chicken meat observed significant $(\mathrm{P}<0.05)$ in all cases. Protein, TBA number and water activity of vacuum packaged sample were found significantly higher $(\mathrm{P}<0.05)$ than conventional packaged and sodium chloride plus sodium nitrite treated chicken meat (treated sample) were detected significantly higher $(\mathrm{P}<0.05)$ than sodium chloride treated only (raw sample). Protein content were found decreased both in vacuum as well as conventional packaged sample throughout storage but TBA number and water activity were found increased significantly $(\mathrm{P}<0.05)$ during storage in all cases. The dried chicken meat was acceptable at the 150 days of storage period.

KEY WORDS : Dried chicken meat, Water activity, TBA number, Protein content, Packaging methods

How to cite this paper : Akhtar, Javeed and Omre, P.K. (2016). Study on effect on water activity, TBA number and protein of dried chicken meat during storage. Internat. J. Proc. \& Post Harvest Technol., 7 (2) : 284290. DOI: 10.15740/HAS/IJPPHT/7.2/284-290. 